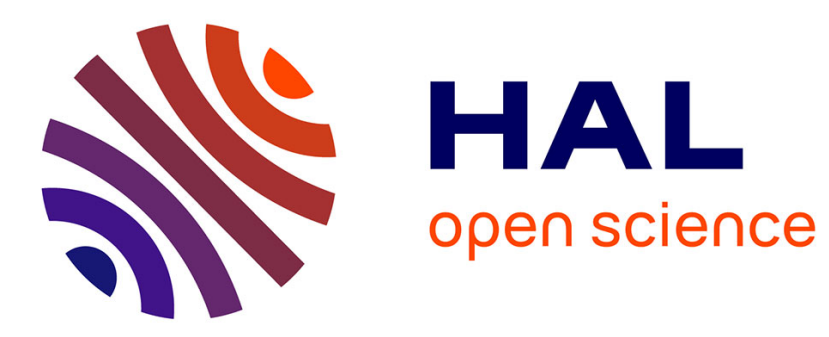

\title{
Continuous flow ring-closing metathesis, an environmentally-friendly route to 2,5-dihydro-1H-pyrrole-3-carboxylates
}

\author{
Marcin Drop, Xavier Bantreil, Katarzyna Grychowska, Gilbert Umuhire \\ Mahoro, Evelina Colacino, Maciej Pawlowski, Jean Martinez, Gilles Subra, \\ Pawel Zajdel, Frédéric Lamaty
}

\section{To cite this version:}

Marcin Drop, Xavier Bantreil, Katarzyna Grychowska, Gilbert Umuhire Mahoro, Evelina Colacino, et al.. Continuous flow ring-closing metathesis, an environmentally-friendly route to 2,5-dihydro- $1 \mathrm{H}$ pyrrole-3-carboxylates. Green Chemistry, 2017, 19 (7), pp.1647-1652. 10.1039/c7gc00235a . hal02385309

\section{HAL Id: hal-02385309 https://hal.science/hal-02385309}

Submitted on 4 Jan 2021

HAL is a multi-disciplinary open access archive for the deposit and dissemination of scientific research documents, whether they are published or not. The documents may come from teaching and research institutions in France or abroad, or from public or private research centers.
L'archive ouverte pluridisciplinaire $\mathbf{H A L}$, est destinée au dépôt et à la diffusion de documents scientifiques de niveau recherche, publiés ou non, émanant des établissements d'enseignement et de recherche français ou étrangers, des laboratoires publics ou privés. 


\title{
Continuous flow ring-closing metathesis, an environmentally-friendly route to 2,5 -dihydro- $1 \mathrm{H}$ - pyrrole-3-carboxylates $\uparrow$
}

\author{
Marcin Drop, ${ }^{a}$ Xavier Bantreil, ${ }^{\mathrm{b}}$ Katarzyna Grychowska, ${ }^{a}$ Gilbert Umuhire Mahoro, ${ }^{\mathrm{b}}$ \\ Evelina Colacino, ${ }^{b}$ Maciej Pawłowski, ${ }^{a}$ Jean Martinez, ${ }^{b, c}$ Gilles Subra, ${ }^{c}$ Pawel Zajdel $^{a}$ \\ and Frédéric Lamaty*b
}

\begin{abstract}
2,5-Dihydro- $1 \mathrm{H}$-pyrrole-3-carboxylates are important building blocks for the synthesis of high value pyrroles and pyrroloquinoline derivatives with interesting biological activities. The use of continuous flow allowed us to perform a key synthetic step, namely ruthenium-catalyzed ring-closing metathesis, with a residence time of $1 \mathrm{~min}$ at $120{ }^{\circ} \mathrm{C}$. Dimethyl carbonate, a green solvent, was demonstrated for the first time to be an excellent solvent for this reaction in continuous flow. The continuous flow conditions proved to be general and the scale-up of this reaction was not only possible, but also highly efficient. Conversion of 10 grams of diene was realized in 37 minutes under continuous flow, yielding the desired heterocycle in $91 \%$ yield.
\end{abstract}

\section{Introduction}

Olefin metathesis is increasingly used at the industrial level for the synthesis of API (Active Pharmaceutical Ingredients). ${ }^{1}$ For example, ring-closing metathesis (RCM) was applied in the synthesis of ciluprevir (BILN-2061), a pseudopeptide inhibitor of HCV NS3 protease (Fig. 1). ${ }^{2}$ Vaniprevir (MH-7009), a ciluprevir analog whose synthesis also requires a RCM step, is now being evaluated in phase III clinical trials. ${ }^{3}$ The six-membered ring oseltamivir phosphate, also known as Tamiflu, and used in the treatment of influenza, could also be synthesized thanks to a RCM process. ${ }^{4}$ The seven-membered heterocyclic ring in SB-462795, a cathepsin K inhibitor for the treatment of osteoporosis, was also obtained using RCM as a key step. ${ }^{5}$

${ }^{a}$ Department of Medicinal Chemistry, Jagiellonian University Medical College, 9 Medyczna Street, 30-688 Krakow, Poland

${ }^{b}$ Institut des Biomolécules Max Mousseron (IBMM) UMR 5247, CNRS, Université de Montpellier, ENSCM, Université de Montpellier, Campus Triolet Place Eugène Bataillon, 34095 Montpellier cedex 5, France.

E-mail: frederic.lamaty@umontpellier.fr

${ }^{c}$ Institut des Biomolécules Max Mousseron (IBMM) UMR 5247, CNRS, Université de Montpellier, ENSCM, Bâtiment E, Faculté de Pharmacie 15, avenue Charles Flahault BP14491, 34093 Montpellier cedex 5, France
In this context, besides our general interest in olefin metathesis, specifically using greener solvents such as poly(ethylene)glycol, glycerol and water, ${ }^{6}$ we recently demonstrated that 2,5-dihydro- $1 H$-pyrrole-3-carboxylates could be obtained via ring-closing metathesis (RCM) using ethyl acetate as a solvent and $1 \mathrm{~mol} \%$ of $\mathbf{N O}_{2}$-Grela ${ }^{7}$ as a catalyst (Fig. 2). These compounds were then converted efficiently into the corresponding pyrroles, which are highly versatile building blocks for biologically active compounds (Scheme 1). ${ }^{8}$ We also demonstrated that the 2,5-dihydro- $1 H$-pyrrole-3-carboxylate 2a was a highly significant intermediate in the synthesis of pyrroloquinolines, ${ }^{9}$ which behave as $5-\mathrm{HT}_{6}$ receptor neutral antagonists. These compounds, displaying pro-cognitive properties, might be useful in the treatment of the cognitive decline associated with Alzheimer's disease and cognitive disorders caused by genetic abnormalities. ${ }^{9 a, 10}$ Ring-closing metathesis on substrates similar to 1a, bearing an electron-withdrawing group on the olefin, is usually more difficult than RCM of benchmark substrates such as diallyltosyl amine. ${ }^{11}$ An improvement of the

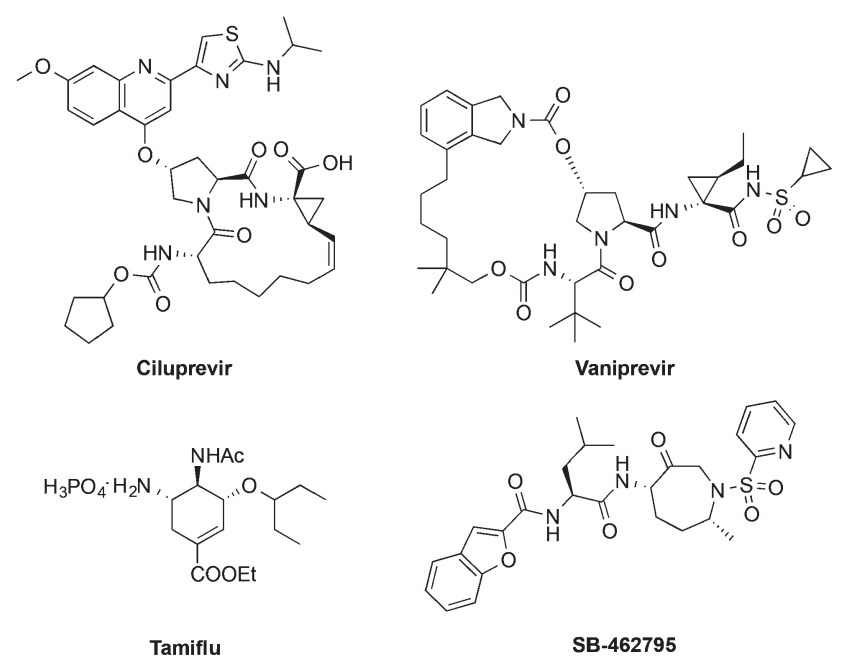

Fig. 1 Pharmaceutical drugs synthesized using olefin metathesis. 


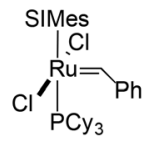

G-II

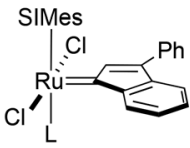

M2, $L=P C y_{3}$

$M 2_{0}, L=P P h_{3}$

$M 3_{1}, L=P y$

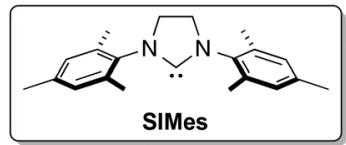

Fig. 2 Structure of the catalysts screened in this study.
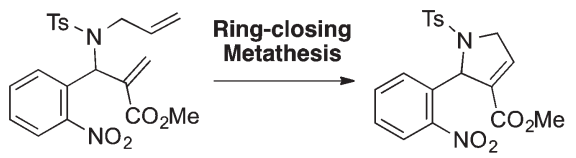

$1 a$

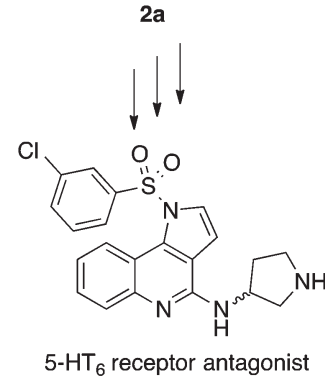

Scheme 1 Synthesis of high value molecules through metathesis. ${ }^{9 a}$

method consisted in performing the reaction under microwave activation, which allowed reducing the reaction time to 5 min. ${ }^{9 c, 11 b, g, h}$ However, scalability of the microwave conditions still represents a huge challenge for this method. One efficient way to circumvent this issue would be to use continuous flow chemistry. Indeed, high temperature microwave synthesis could be easily translated to continuous flow synthesis, since both techniques allow efficient heating/cooling and generation of a superheated solvent. ${ }^{12}$ In order to obtain the reaction conditions that could be applicable on even a larger scale, we decided to focus on the RCM of 1a using continuous flow chemistry. Continuous flow is increasingly prevalent in organic chemistry, ${ }^{13}$ providing several advantages over batch synthesis. ${ }^{14}$ As small quantities of reagents are in contact with each other in microfluidic systems, a perfect control of stoichiometry, ${ }^{15}$ important for the selectivity of reactions, as well as the control of exothermic reactions, ${ }^{16}$ could be envisaged. In addition, versatile conditions, in terms of temperature, pressure and flow rates, could be applied to facilitate the optimisation process.
Literature reports dealing with ruthenium-catalyzed metathesis under continuous flow conditions remain scarce ${ }^{17}$ and focus mostly on the development of heterogeneous catalysts. ${ }^{18}$ Since, for the moment, most heterogeneous catalysts show limited recyclability, our approach was to focus on the development of environmentally friendly conditions using easily available homogeneous catalysts.

\section{Results and discussion}

Reactions were performed using a Uniqsis Flowsyn system, and reagents (substrates and catalysts) were dissolved together in a single reservoir bottle prior to pumping into the residence coil. To make sure that this methodology could be robust and practically scalable, reactions were performed in air using ACS grade solvents, without degassing or drying. Second generation commercially available catalysts, bearing $N, N^{\prime}$-bis(2,4,6-trimethylphenyl)imidazolin-2-ylidene (SIMes) as the NHC ligand, from different families, were tested (Fig. 2). Benzylidene $\left(\mathbf{G}-\mathbf{I I}^{19}\right)$, boomerang-type (HG-II ${ }^{20}$ and $\left.\mathbf{N O}_{2}-\mathbf{G r e l a}^{7}\right)$, "Scorpio"21 $\left(\mathbf{M} 5_{1}{ }^{22}\right.$ and $\left.\mathbf{M 5}_{2}{ }^{23}\right)$ and robust indenylidene ${ }^{24}\left(\mathbf{M} 2{ }^{25} \mathbf{M} 2_{\mathbf{0}}\right.$, $\mathbf{M} 3_{1}, \mathbf{M} 2_{2}{ }^{26}$ ) catalysts were screened in the RCM of compound 1a, with an $o-\mathrm{NO}_{2}$ phenyl ring, in dichloromethane as a solvent, at $90{ }^{\circ} \mathrm{C}$, with a residence time of $30 \mathrm{~min}$ and $3 \mathrm{~mol} \%$ of ruthenium catalyst (Table 1 , entry 1 ). Pre-catalysts $\mathbf{M 5}_{\mathbf{1}}$, HG-II, M2 and $\mathbf{M} 2_{0}$, which are more resistant to temperature than G-II, $\mathbf{N O}_{2}$-Grela, $\mathbf{M 5}_{\mathbf{2}}$ and $\mathbf{M} \mathbf{3}_{\mathbf{1}}$, gave the best HPLC conversions (up to 98\%). Using $\mathbf{M} 2$ as a catalyst, reducing the catalyst loading from 3 to $2 \mathrm{~mol} \%$ was detrimental to the reaction. While decreasing the residence time to $20 \mathrm{~min}$ at $90{ }^{\circ} \mathrm{C}$ resulted in a lower conversion, a concomitant increase of temperature to $110{ }^{\circ} \mathrm{C}$ allowed us to obtain $94 \%$ conversion in only $5 \mathrm{~min}^{27}$ It is important to note that traces (up to $5 \%$ ) of isomerization of $\mathbf{1 a}$, resulting from the formation of a ruthenium hydride species, ${ }^{6 b}$ were detected in the crude reaction mixtures; interestingly, the percentage of isomerization was below $1 \%$ when $\mathbf{M} 5_{2}, \mathbf{M} 2, \mathbf{M} 2_{0}$ and $\mathbf{M} 3_{1}$ were used. $^{27}$

Although these conditions could be suitable for efficient RCM, in a continuous effort to find environmentally friendly conditions, ${ }^{6 a-e}$ we decided to search for a greener solvent than dichloromethane. Previous studies in batch showed that ethyl acetate and dimethyl carbonate (DMC) could be suitable solvents for RCM. ${ }^{28}$ In addition, these solvents were classified as non-toxic for the industrial synthesis of API. ${ }^{29}$ Since it was an appropriate solvent for the RCM of $\mathbf{1 a}$ in batch, ${ }^{8}$ ethyl acetate was first tested (Table 1, entry 2). Reactions using HG-II, M5 and $\mathbf{M} 2_{2}$ gave interesting HPLC conversions (>85\%) in AcOEt, but the results were not better than those in dichloromethane. DMC was then evaluated in continuous flow RCM for the first time, to the best of our knowledge. To our delight, catalysts HG-II and M2 gave excellent results under the conditions tested. Catalyst $\mathbf{M 2}$, which is a highly stable indenylidene-type pre-catalyst, allowed reaching almost full conversion when reactions were performed at $110{ }^{\circ} \mathrm{C}$ for $5 \mathrm{~min}$ or at $120{ }^{\circ} \mathrm{C}$ for 1 min (Table 1, entries 6-8). However, HG-II gave a lower con- 


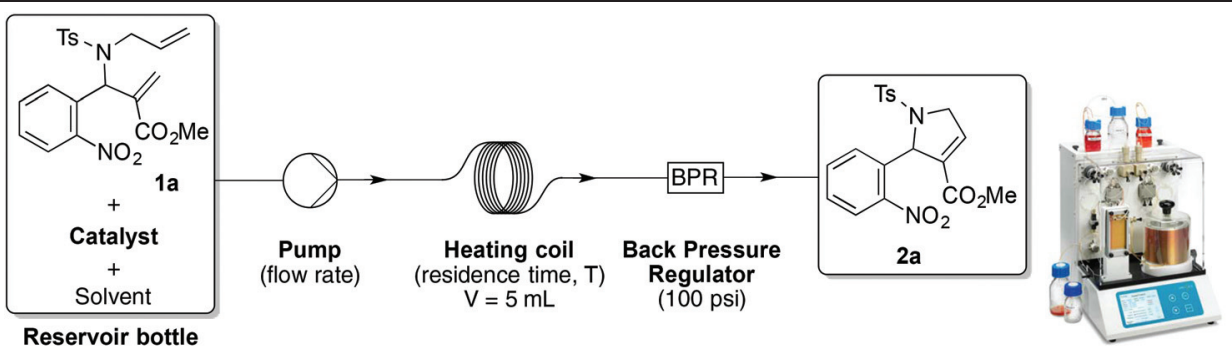

\begin{tabular}{|c|c|c|c|c|c|c|c|c|c|c|c|c|}
\hline \multirow[b]{2}{*}{ Entry } & \multirow[b]{2}{*}{ Solvent } & \multirow[b]{2}{*}{$T\left({ }^{\circ} \mathrm{C}\right)$} & \multirow[b]{2}{*}{ Res. time (min) } & \multicolumn{9}{|c|}{ HPLC conv. (\%) } \\
\hline & & & & G-II & $\mathrm{NO}_{2}$-Grela & HG-II & M5 & $\mathbf{M 5}_{2}$ & M2 & $\mathbf{M} 2_{\mathbf{0}}$ & $\mathbf{M 3}_{1}$ & $\mathbf{M}_{2}$ \\
\hline 1 & $\mathrm{CH}_{2} \mathrm{Cl}_{2}$ & 90 & 30 & 72 & 74 & 94 & 96 & 14 & $98(84)^{b}$ & 94 & 25 & 35 \\
\hline 2 & AcOEt & 90 & 30 & 75 & 73 & 95 & 85 & 22 & 23 & 60 & 23 & 88 \\
\hline 3 & DMC & 90 & 30 & 74 & 84 & 94 & 82 & 10 & 98 & 50 & 21 & 75 \\
\hline 4 & DMC & 110 & 5 & 76 & 85 & 94 & 78 & 7 & 98 & 57 & 11 & 77 \\
\hline 5 & & 120 & 1 & 71 & 73 & 85 & 69 & 5 & 96 & 46 & 19 & 53 \\
\hline 6 & & 130 & 5 & & & & & & & & & 92 \\
\hline
\end{tabular}

${ }^{a}$ Reaction conditions: 1a $(0.125 \mathrm{mmol})$, catalyst $(3 \mathrm{~mol} \%)$, solvent $(1 \mathrm{~mL}), T$, residence time; HPLC conversions of 1a into $2 \mathrm{a}$ are given. See Table S1 in ESI for the complete optimization. ${ }^{b} 2 \mathrm{~mol} \%$ catalyst were used.

version at $120^{\circ} \mathrm{C}$, probably because of a slightly lower thermal stability. Additionally, isomerisation of $\mathbf{1 a}$ was observed when HG-II was used (up to 5\%). Finally, a third interesting set of conditions was found with catalyst $\mathbf{M} 2_{2}$, which has a latent character that already proved to be useful in RCM and polymerisation reactions. ${ }^{26,30}$ At $130{ }^{\circ} \mathrm{C}$, catalyst $\mathbf{M} 2_{2}$ gave $92 \%$ conversion within only 5 min reaction (Table 1 , entry 6).

As stated above, reactions were run using one solution that was pumped into the residence coil. Since catalyst decomposition could occur rapidly when the catalyst is in the presence of an alkene substrate, through the formation of a ruthenium methylidene species, ${ }^{31}$ reactions were also performed using two separate solutions, one containing the substrate 1a, and the other one containing the catalyst. Catalyst M2, which is temperature stable and gave the best results in DMC, and $\mathbf{M} 3_{\mathbf{1}}$, which activates faster and thus is more prone to decomposition, were tested. Then, the substrate and catalyst solutions were pumped at the same flow rate and mixed in a coil heated at $120^{\circ} \mathrm{C}$. After a residence time of $1 \mathrm{~min}$, as for Table 1 , entry 5 ,

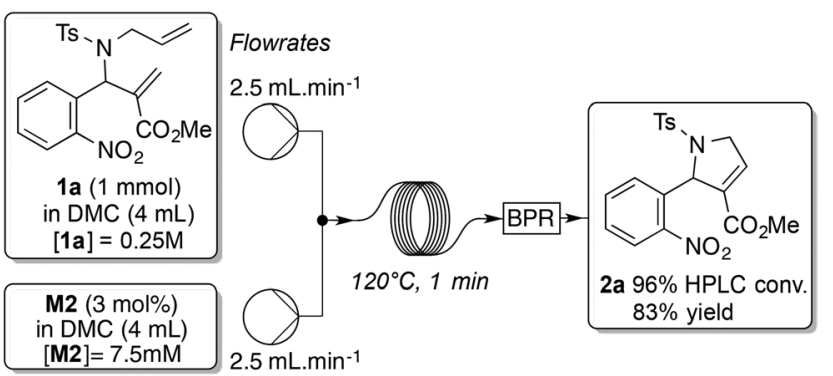

Scheme 2 Continuous flow RCM of 1a using 2 pumps. conversions reached $96 \%$ and $19 \%$ with $\mathbf{M} 2$ and $\mathbf{M} 3_{1}$ resp., similar to the ones obtained in the one pump experiments. This demonstrates that decomposition, if happening, does not distort the results obtained in Table 1 using a single reservoir bottle. Performed on a $1 \mathrm{mmol}$ scale, conditions with $\mathbf{M} 2 \mathrm{using}$ two separate solutions gave, after $1 \mathrm{~min}$ residence time at $120{ }^{\circ} \mathrm{C}$, filtration over silica, evaporation and precipitation in diethyl ether, the cyclized compound $2 \mathrm{a}$ in $83 \%$ yield (Scheme 2). Such a result permits to envision the use of an automated system, allowing the screening of substrates or catalysts.

In the next step, we investigated the utility of the developed method for the RCM of compounds $\mathbf{1 b}-\mathbf{g}$, bearing different substituents on the phenyl ring (Scheme 3). Two sets of experimental conditions (A: $110^{\circ} \mathrm{C}$ for $5 \mathrm{~min}$ and $\mathrm{B}: 120^{\circ} \mathrm{C}$ for $1 \mathrm{~min}$ ) were compared using substrates 1a-d to select the one that would give the best results. Compounds $2 \mathbf{a}-\mathbf{d}$, bearing respectively a nitro group, a chlorine atom, a methoxy group or a hydrogen atom in ortho position of the phenyl ring, were obtained through RCM, after evaporation and precipitation in diethyl ether. Experimental conditions B resulted in a shorter reaction time and provided slightly better yields. Conditions B were thus selected and applied to substrates $\mathbf{1 e - g}$, bearing a chlorine atom or a methoxy group either in meta or para position of the phenyl ring. Compounds $2 \mathbf{e}, \mathbf{2 f}$ and $2 \mathbf{g}$ were isolated in $52 \%, 68 \%$ and $81 \%$ yields, respectively. In all cases, conversion was almost complete and neither degradation nor intermolecular unwanted side reactions that would have given dimer side-products was observed. Moderate yields were mainly due to incomplete precipitation during product isolation. ${ }^{27}$

Continuous flow is an innovative technology since, once optimal conditions are found, they can be directly applied for reaction scale-up. The RCM of $10 \mathrm{~g}$ ( $23 \mathrm{mmol}$ ) of compound 1a 


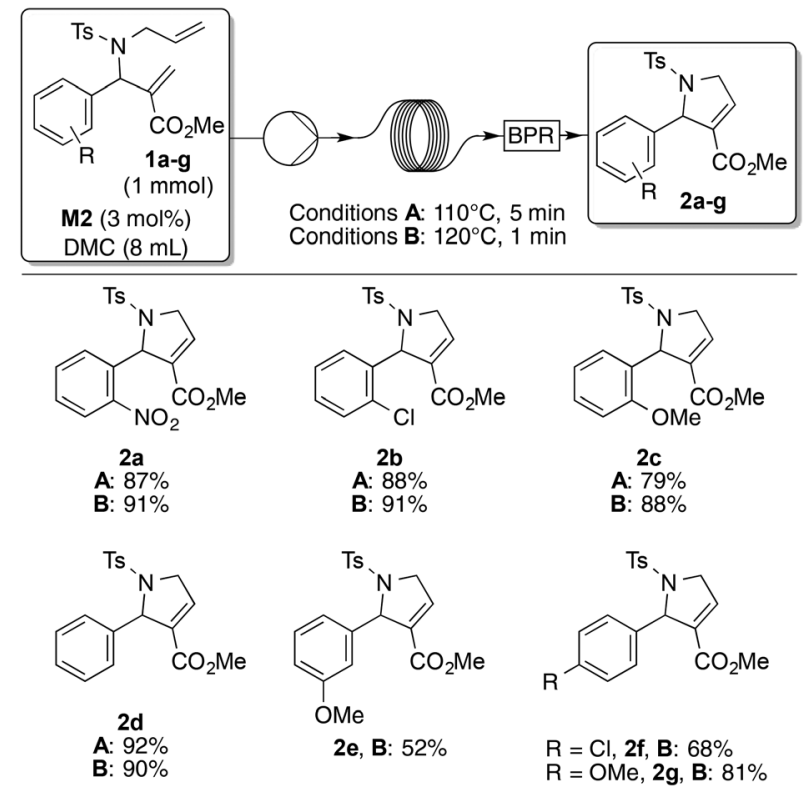

Scheme 3 Continuous flow metathesis of substrates $1 \mathbf{a}-\mathbf{g}$. Reaction conditions: $1 \mathrm{a}-\mathrm{g}(1.0 \mathrm{mmol}), \mathrm{M} 2(3 \mathrm{~mol} \%), \mathrm{DMC}(8 \mathrm{~mL}), 110{ }^{\circ} \mathrm{C}, 5 \mathrm{~min}$ (conditions A) or $120^{\circ} \mathrm{C}, 1 \mathrm{~min}$ (conditions $\mathrm{B}$ ). Isolated yields are given.

was thus attempted, using $3 \mathrm{~mol} \%$ of $\mathbf{M} 2$ catalyst in DMC, with a reaction coil heated at $120^{\circ} \mathrm{C}$ and a flow rate to ensure a $1 \mathrm{~min}$ residence time. Gratifyingly, $10 \mathrm{~g}$ of substrate were pumped into the continuous flow system within $37 \mathrm{~min}$ and the cyclized dihydropyrrole 2 a could be isolated in 91\% yield, which is exactly the same yield as that obtained on a $1 \mathrm{mmol}$ scale (Scheme 4). In comparison, RCM of $15 \mathrm{~g}$ of $1 \mathrm{a}$ in batch gave less satisfying results. ${ }^{8}$ To confirm that the RCM reaction proceeded in the reaction coil and not in the reservoir bottle before pumping into the coil, the conversion was checked, in the reservoir solution, after $37 \mathrm{~min}$. Less than $5 \%$ conversion was measured, demonstrating that the RCM process required heating at $120^{\circ} \mathrm{C}$ in continuous flow.

Since HG-II is one of the most used catalysts for API synthesis, it was also evaluated on a larger scale using conditions from Table 1 , entry 4 . Thus, on a $2 \mathrm{mmol}$ scale with a residence time of $5 \mathrm{~min}$ at $110{ }^{\circ} \mathrm{C}$ in DMC, the cyclized compound 2a was isolated in $92 \%$ yield. The total reaction time was $16 \mathrm{~min}$ in this case. HG-II is thus a good candidate for large scale RCM, even though, on the same scale, the total reaction time would be longer than that with M2. In addition, isomeri-

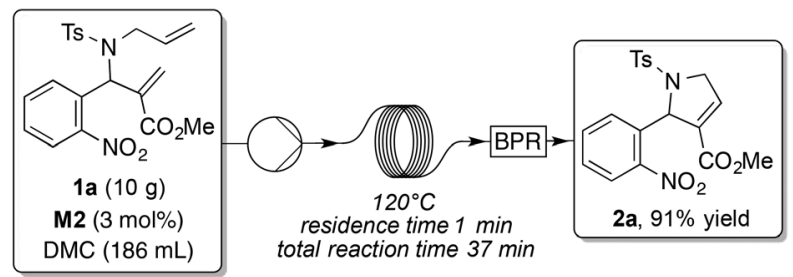

Scheme 4 Continuous flow RCM of $10 \mathrm{~g}$ of $1 \mathrm{a}$ in $37 \mathrm{~min}$. zation of 1a also occurred on this scale; the undesired isomer was separated from 2a upon precipitation, and then isolated and fully characterized. ${ }^{27}$

\section{Conclusions}

We reported in this study a highly efficient continuous flow protocol allowing the ring-closing metathesis of dienes $\mathbf{1 a}-\mathbf{g}$ to obtain 2,5-dihydro- $1 H$-pyrroles $2 \mathbf{a}$-g. We demonstrated that dimethyl carbonate, an environmentally friendly solvent, was an excellent solvent for the metathesis reaction in flow, which could be completed within $1 \mathrm{~min}$ at $120{ }^{\circ} \mathrm{C}$. In addition, scaling-up the reaction using continuous flow, from 1 to $23 \mathrm{mmol}$, did not change the outcome of the ring-closing metathesis, and yielded the cyclized compound 2a in $91 \%$ yield after $37 \mathrm{~min}$.

\section{Acknowledgements}

We acknowledge the financial support from the University of Montpellier, CNRS, National Science Center, Poland (grant no. 2016/21/B/NZ7/01742), Institut Carnot Chimie Balard through ANR programme no. 11 CARN 0001-01, and the PHC Polonium programme (French Embassy in Poland/French Ministry of Foreign Affairs and International Development). M. D. thanks the Erasmus+ Programme for a fellowship. Umicore AG \& Co. KG is gratefully acknowledged for the gift of catalysts $\mathbf{M 2}, \mathbf{M} 2_{\mathbf{0}}$, $\mathbf{M} 3_{1}, \mathbf{M} 5_{1}$ and $\mathbf{M} 5_{2}$. Materia, Inc. is gratefully acknowledged for the gift of the catalyst HG-II.

\section{Notes and references}

1 (a) C. S. Higman, J. A. M. Lummiss and D. E. Fogg, Angew. Chem., Int. Ed., 2016, 55, 3552; (b) G. Trimmel and C. Slugovc, Monatsh. Chem., 2015, 146, 1031.

2 M. Llinas-Brunet, M. D. Bailey, G. Bolger, C. Brochu, A.-M. Faucher, J. M. Ferland, M. Garneau, E. Ghiro, V. Gorys, C. Grand-Maitre, T. Halmos, N. Lapeyre-Paquette, F. Liard, M. Poirier, M. Rheaume, Y. S. Tsantrizos and D. Lamarre, J. Med. Chem., 2004, 47, 1605.

3 (a) J. A. McCauley, C. J. McIntyre, M. T. Rudd, K. T. Nguyen, J. J. Romano, J. W. Butcher, K. F. Gilbert, K. J. Bush, M. K. Holloway, J. Swestock, B.-L. Wan, S. S. Carroll, J. M. DiMuzio, D. J. Graham, S. W. Ludmerer, S.-S. Mao, M. W. Stahlhut, C. M. Fandozzi, N. Trainor, D. B. Olsen, J. P. Vacca and N. J. Liverton, J. Med. Chem., 2010, 53, 2443; (b) N. J. Liverton, S. S. Carroll, J. Dimuzio, C. Fandozzi, D. J. Graham, D. Hazuda, M. K. Holloway, S. W. Ludmerer, J. A. McCauley, C. J. McIntyre, D. B. Olsen, M. T. Rudd, M. Stahlhut and J. P. Vacca, Antimicrob. Agents Chemother., 2010, 54, 305.

4 (a) H.-S. Oh and H.-Y. Kang, J. Org. Chem., 2012, 77, 8792; (b) X. Cong and Z.-J. Yao, J. Org. Chem., 2006, 71, 5365. 
5 H. Wang, H. Matsuhashi, B. D. Doan, S. N. Goodman, X. Ouyang and W. M. Clark, Tetrahedron, 2009, 65, 6291.

6 (a) L. Laville, C. Charnay, F. Lamaty, J. Martinez and E. Colacino, Chem. - Eur. J., 2012, 18, 760; (b) X. Bantreil, M. Sidi-Ykhlef, L. Aringhieri, E. Colacino, J. Martinez and F. Lamaty, J. Catal., 2012, 294, 113; (c) E. Colacino, J. Martinez and F. Lamaty, Coord. Chem. Rev., 2007, 251, 726; (d) N. Bakhrou, F. Lamaty, J. Martinez and E. Colacino, Tetrahedron Lett., 2010, 51, 3935; (e) M. Sacco, C. Charnay, F. De Angelis, M. Radoiu, F. Lamaty, J. Martinez and E. Colacino, RSC Adv., 2015, 5, 16878.

7 (a) K. Grela, S. Harutyunyan and A. Michrowska, Angew. Chem., Int. Ed., 2002, 41, 4038; (b) A. Michrowska, R. Bujok, S. Harutyunyan, V. Sashuk, G. Dolgonos and K. Grela, J. Am. Chem. Soc., 2004, 126, 9318.

8 K. Grychowska, B. Kubica, M. Drop, E. Colacino, X. Bantreil, M. Pawłowski, J. Martinez, G. Subra, P. Zajdel and F. Lamaty, Tetrahedron, 2016, 72, 7462.

9 (a) K. Grychowska, G. Satala, T. Kos, A. Partyka, E. Colacino, S. Chaumont-Dubel, X. Bantreil, A. Wesolowska, M. Pawlowski, J. Martinez, P. Marin, G. Subra, A. J. Bojarski, F. Lamaty, P. Popik and P. Zajdel, ACS Chem. Neurosci., 2016, 7, 972; (b) P. Zajdel, K. Grychowska, F. Lamaty, E. Colacino, X. Bantreil, J. Martinez, M. Pawlowski, G. Satala, A. J. Bojarski, A. Partyka, A. Wesolowska, T. Kos, P. Popik and G. Subra, WO 2015012704A1, 2015; (c) H. Benakki, E. Colacino, C. Andre, F. Guenoun, J. Martinez and F. Lamaty, Tetrahedron, 2008, 64, 5949.

10 W. Deraredj Nadim, S. Chaumont-Dubel, F. Madouri, L. Cobret, M.-L. De Tauzia, P. Zajdel, H. Bénédetti, P. Marin and S. Morisset-Lopez, Proc. Natl. Acad. Sci. U. S. A., 2016, 113, 12310.

11 (a) J. M. Kim, K. Y. Lee, S. Lee and J. N. Kim, Tetrahedron Lett., 2004, 45, 2805; (b) V. Declerck, P. Ribière, J. Martinez and F. Lamaty, J. Org. Chem., 2004, 69, 8372; (c) S. Varray, R. Lazaro, J. Martinez and F. Lamaty, Organometallics, 2003, 22, 2426; (d) T. A. Kirkland and R. H. Grubbs, J. Org. Chem., 1997, 62, 7310; (e) L. Hyldtoft and R. Madsen, J. Am. Chem. Soc., 2000, 122, 8444; (f) S. Gessler, S. Randl and S. Blechert, Tetrahedron Lett., 2000, 41, 9973; $(g)$ C. Yang, W. V. Murray and L. J. Wilson, Tetrahedron Lett., 2003, 44, 1783; (h) D. Balan and H. Adolfsson, Tetrahedron Lett., 2004, 45, 3089.

12 T. Razzaq and C. O. Kappe, Chem. - Asian J., 2010, 5, 1274.

13 R. Porta, M. Benaglia and A. Puglisi, Org. Process Res. Dev., 2016, 20, 2.

14 (a) L. Vaccaro, D. Lanari, A. Marrocchi and G. Strappaveccia, Green Chem., 2014, 16, 3680; (b) J. C. Pastre, D. L. Browne and S. V. Ley, Chem. Soc. Rev., 2013, 42, 8849; (c) B. Gutmann, D. Cantillo and C. O. Kappe, Angew. Chem., Int. Ed., 2015, 54, 6688; (d) S. V. Ley, D. E. Fitzpatrick, R. M. Myers, C. Battilocchio and R. J. Ingham, Angew. Chem., Int. Ed., 2015, 54, 10122; (e) S. V. Ley, D. E. Fitzpatrick, R. J. Ingham and R. M. Myers, Angew. Chem., Int. Ed., 2015, 54, 3449.
15 (a) T. Fukuyama, H. Chiba, H. Kuroda, T. Takigawa, A. Kayano and K. Tagami, Org. Process Res. Dev., 2016, 20, 503; (b) D. Webb and T. F. Jamison, Org. Lett., 2012, 14, 2465.

16 (a) B. J. Deadman, S. G. Collins and A. R. Maguire, Chem. Eur. J., 2015, 21, 2298; (b) M. Movsisyan, E. I. P. Delbeke, J. K. E. T. Berton, C. Battilocchio, S. V. Ley and C. V. Stevens, Chem. Soc. Rev., 2016, 45, 4892.

17 (a) K. A. Alexander, E. A. Paulhus, G. M. L. Lazarus and N. E. Leadbeater, J. Organomet. Chem., 2016, 812, 74; (b) E. Comer and M. G. Organ, J. Am. Chem. Soc., 2005, 127, 8160; (c) C. Schotten, D. Plaza, S. Manzini, S. P. Nolan, S. V. Ley, D. L. Browne and A. Lapkin, ACS Sustainable Chem. Eng., 2015, 3, 1453.

18 (a) E. Riva, A. Rencurosi, S. Gagliardi, D. Passarella and M. Martinelli, Chem. - Eur. J., 2011, 17, 6221; (b) K. Skowerski, C. Wierzbicka and K. Grela, Curr. Org. Chem., 2013, 17, 2740; (c) R. Duque, E. Ochsner, H. Clavier, F. Caijo, S. P. Nolan, M. Mauduit and D. J. Cole-Hamilton, Green Chem., 2011, 13, 1187; (d) A. Michrowska, K. Mennecke, U. Kunz, A. Kirschning and K. Grela, J. Am. Chem. Soc., 2006, 128, 13261; (e) W. Solodenko, A. Doppiu, R. Frankfurter, C. Vogt and A. Kirschning, Aust. J. Chem., 2013, 66, 183; (f) R. Munirathinam, J. Huskens and W. Verboom, Adv. Synth. Catal., 2015, 357, 1093; $(g)$ M. Bru, R. Dehn, J. H. Teles, S. Deuerlein, M. Danz, I. B. Müller and M. Limbach, Chem. - Eur. J., 2013, 19, 11661; (h) E. Borré, M. Rouen, I. Laurent, M. Magrez, F. Caijo, C. Crévisy, W. Solodenko, L. Toupet, R. Frankfurter, C. Vogt, A. Kirschning and M. Mauduit, Chem. - Eur. J., 2012, 18, 16369; (i) E. J. O’Neal and K. F. Jensen, ChemCatChem, 2014, 6, 3004; (j) K. Skowerski, S. J. Czarnocki and P. Knapkiewicz, ChemSusChem, 2014, 7, 536.

19 M. Scholl, S. Ding, C. W. Lee and R. H. Grubbs, Org. Lett., 1999, 1, 953.

20 S. B. Garber, J. S. Kingsbury, B. L. Gray and A. H. Hoveyda, J. Am. Chem. Soc., 2000, 122, 8168.

21 S. Guidone, E. Blondiaux, C. Samojłowicz, Ł. Gułajski, M. Kędziorek, M. Malińska, A. Pazio, K. Woźniak, K. Grela, A. Doppiu and C. S. J. Cazin, Adv. Synth. Catal., 2012, 354, 2734.

22 D. Arlt, M. Bieniek and R. Karch, WO 2008034552A1, 2008.

23 M. Bieniek, C. Samojłowicz, V. Sashuk, R. Bujok, P. Śledź, N. Lugan, G. Lavigne, D. Arlt and K. Grela, Organometallics, 2011, 30, 4144.

24 (a) V. Dragutan, I. Dragutan and F. Verpoort, Platinum Met. Rev., 2005, 49, 33; (b) M. Bieniek, A. Michrowska, D. L. Usanov and K. Grela, Chem. - Eur. J., 2008, 14, 806; (c) F. Boeda, X. Bantreil, H. Clavier and S. P. Nolan, Adv. Synth. Catal., 2008, 350, 2959.

25 (a) H. Clavier and S. P. Nolan, Chem. - Eur. J., 2007, 13, 8029; (b) S. Monsaert, R. Drozdzak, V. Dragutan, I. Dragutan and F. Verpoort, Eur. J. Inorg. Chem., 2008, 432.

26 X. Bantreil, T. E. Schmid, R. A. M. Randall, A. M. Z. Slawin and C. S. J. Cazin, Chem. Commun., 2010, 46, 7115. 
28 (a) K. Skowerski, J. Białecki, A. Tracz and T. K. Olszewski, Green Chem., 2014, 16, 1125; (b) C. Bruneau and C. Fischmeister, Olefin metathesis in green organic solvents and without solvent, John Wiley \& Sons, Inc., 2014, pp. 523-535; (c) H. Bilel, N. Hamdi, F. Zagrouba, C. Fischmeister and C. Bruneau, Green Chem., 2011, 13, 1448; (d) C. S. Adjiman, A. J. Clarke, G. Cooper and P. C. Taylor, Chem. Commun., 2008, 2806; (e) V. Le Ravalec, A. Dupe, C. Fischmeister and C. Bruneau, ChemSusChem, 2010, 3, 1291; (f) A. Keraani, C. Fischmeister, T. Renouard, M. Le Floch, A. Baudry, C. Bruneau and M. RabillerBaudry, J. Mol. Catal. A: Chem., 2012, 357, 73.
29 (a) R. K. Henderson, C. Jimenez-Gonzalez, D. J. C. Constable, S. R. Alston, G. G. A. Inglis, G. Fisher, J. Sherwood, S. P. Binks and A. D. Curzons, Green Chem., 2011, 13, 854; (b) D. Prat, O. Pardigon, H.-W. Flemming, S. Letestu, V. Ducandas, P. Isnard, E. Guntrum, T. Senac, S. Ruisseau, P. Cruciani and P. Hosek, Org. Process Res. Dev., 2013, 17, 1517; (c) D. Prat, J. Hayler and A. Wells, Green Chem., 2014, 16, 4546.

30 X. Bantreil and C. J. Cazin, Monatsh. Chem., 2015, 146, 1043.

31 (a) C. S. Higman, A. E. Lanterna, M. L. Marin, J. C. Scaiano and D. E. Fogg, ChemCatChem, 2016, 8, 2446; (b) S. H. Hong, A. G. Wenzel, T. T. Salguero, M. W. Day and R. H. Grubbs, J. Am. Chem. Soc., 2007, 129, 7961. 